\title{
Highlighting the Cognitive Objectives on Writing Skill Development: The Creativity Paradigm
}

\author{
Akinwamide Timothy Kolade (PhD)* \\ Ekiti State University, Arts and Language Education Department Ado Ekiti, Nigeria \\ *Corresponding Author:Akinwamide Timothy Kolade,Ekiti State University, Arts and Language \\ Education Department Ado Ekiti, Nigeria
}

\begin{abstract}
The quest for creativity means: abhorrence of plagiarism, preference for originality, rejection of stagnation and redundancy. It is a disquieting puzzle on how to achieve this feat among the sub-Saharan multilingual writers where English is a second language. The interference of the first Language (L1) with the second Language (L2) is all pervading. Everyone wants to display the artistic prowess in the writing skill. The resultant effects are writers plagiarizing, irrelevant content package, and illogical organization of ideas, incoherent facts and presentations of obsolete points of view. Attempt is made in this paper to presents the inherent highlights of the Cognitive Approach towards enhancing writers' confidence and independence writing. Hence the paper focuses on three variables - generative instinct development, creativity in writing and originality of write-ups. The first variable-generative instinct development will be made possible by giving vent to writers' innate ideas through the pre-writing techniques like Brainstorming, Observation, Imagining, and Watching of Movie. Ability to generate ideas will lead to creativity which is the second variable. All these eventually will culminate in the third variable which is originality.
\end{abstract}

Keywords: originality, confidence, peer-editing, mind-mapping

\section{INTRODUCTION}

The language skill of writing has been adjudged to be the most complex of all the language skills. It is on this premise that the teacher and the learners should approach the skill through the appropriate philosophical background that enhances faster development. This is in agreement with the views of Bell and Burnaby (1984) that writing is an extremely complex cognitive activity in which the writer is required to demonstrate control of a number of variables simultaneously. By implication, it means the teacher must be well informed about the objectives of different philosophical approaches to the teaching of writing skill and identifies the appropriate approach for the students learning under a given situation.

Nunan (2000) expresses his view that "Writing is not a natural activity. All physically and mentally normal people learn to speak a language. Yet all people have to be taught how to write". It is right from this perspective that the teaching and learning of writing should be organized and accompanied with concerted effort of the language teacher and careful approach of the students.

Complexity also arises in language teaching according to Akinwamide (2009) that highlights the variations among language teachers with regard to teacher's demographics classifications on the teaching of any of the language macro skills. The teacher may speak the language natively or he may have studied it on second language basis, which is true of most teachers in Nigeria. Hence, the teaching of language and its complex skill of writing requires careful planning and appropriate approach to help the students. This is underscored by the view of Akinwamide (2012) that successful writing is an end product of intelligent reasoning and good planning.

In Nigeria, in spite of the fact that second language teachers more often than not teach second language students in a second language situation, the same teachers handle all the macro-skills of language. This allows for a very little time, minimal concentration and inadequate planning for the development of the writing skill. It has been revealed through researches that many of the teachers are not aware that there exist different approaches to the teaching of writing. The teachers just pounce on any known method for classroom practice. The resultant effects of employing inappropriate approach 
are displayed in inability of students to write comprehensively and illogical organization of facts while the teachers' expectations and students' demonstrations are poles apart. Some teachers, in an attempt to cover the syllabus either gloss over or ignore certain basic macro-skills in the easy writing classroom.

Over the years, the problems associated with writing in a Second Language have persisted which means that the conventional approach/method of teaching the skill of writing is ineffective. Hence, the different views and opinions on the nature of writing make investigation into ways of developing the writing skill inevitable and in fact, it is quite essential.The technical nature of writing and the need to organize a writer's thought in a coherent manner and applying the right mechanics demand that it should be taught well for acceptability.

\section{The Philosophical Background to the Cognitive Theory}

The Dissatisfaction of the Mentalists with Behaviorism's full focus on observable behavior led to the demand for an approach to learning theory that focuses more attention on what goes on as the innate ideas of the learners. They developed a cognitive approach that pays attention on the mental processes rather than the observable behavior. Central to the cognitivist ideology is the idea that knowledge is made up of symbolic mental representations, such as propositions and images which innate, together with a mechanism that operates on those representations. Knowledge is seen as something that is constantly constructed by learners based on their existing cognitive structures. Learning is relative to their stage of cognitive development in each learner; understanding the learner's existing intellectual capability is central to understanding the learning process. Therefore, from a psychological point of view, easy writing should be a psychological impulse, an output of emotional vent flowing out of personal life experience, observations and the individual true accounts of issues. The perception and description from individual's knowledge and experience cannot be the same. Independent writing should be a display of students' views on life, to express their inner feelings and put in graphical forms their own spice of life. The attempt to build up the writing skill through mere studying of the work of others as proposed by the model approach may not reveal the true mood nor favor the generating of ideas as the Cognitive advocates. The danger is that students may perceive writing as a mechanical practice and nothing more than producing correct sentences. Though controlled tasks of the model approach could help students to develop accuracy and correctness by engaging in various exercises based on imitation. Nevertheless, when students are to compose using their own sentences, the students end up with many grammatical errors.

\section{The Quest For Creativity In The Language Classroom}

The West African Examinations Council (WAEC) and National Examinations Council (NECO) want the students to be creative in their writing approach. It is imperative to know why creativity in the language classroom is very important especially in a second language environment. Pligrims (2007) itemizes seven facts in respect of this sub-skill development.

(1) Language use is a creative art: We transform thoughts into language that can be heard or seen. We are capable of producing sentences and even long texts that we have never heard or seen before. By giving learners creative exercises, we get them to practice an important sub-skill of using a language; thinking creatively.

(2) Creativity Aids Learning: Some people cannot learn at all if they are not allowed to be creative.

(3) Motivating Power in Inspiration: Some people become motivated as a result of inspiration which makes them to create something of value.

(4) Creativity Improves Self-esteem: This makes learners to look at their own solutions to problems and their own products and see what they are able to achieve.

(5) Creative work in the Language Classroom can lead to genuine communication and cooperation. Learners use the language to do the creative task; so they use it as a tool, in its original function. This prepares learners for using the language instrumentally outside the classroom.

(6) Creative tasks enrich classroom work. This opens the way for exciting and thrilling academic atmosphere. The tasks make the classroom work varied and more innovative by tapping into individual talents; ideas and thoughts - both the learners' and the teachers',

(7) Creative Thinking is an important skill in real life. It is part of our survival strategies and it is a force behind personal growth. 


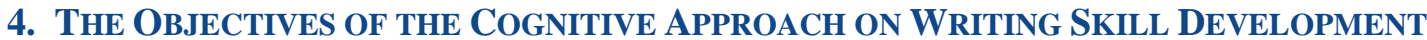

The Cognitive proposes that writers practise different activities at each of three productive stages of writing. This is to say that no model is to be studied before writing. Adam (2006) says in cognitive writing, the first thing that a writer needs to do is to find something to write about. This idea of getting the subject to write about can be facilitated by the teacher in a language classroom. Writing assumes production tasks that prompt self-expression to motivate students as the principal engine for developing proficiency in the language classroom. The inherent methodology is writing of many drafts which is applied to the actual act of composing and writing in the pedagogy of writing and the theory of writing. The basic outlining of the drafts are expressed in a. Prewriting b. Writing c. Final draft (each stage is accompanied with editing)

Prewriting: This technique according to Adams (2007) helps students assess the dimensions of a rhetorical problem and plan its solution. It triggers perceptual and conceptual processes; permitting writers to recall experiences, breakthrough stereotyped thinking, examine relationships between ideas, assess the expectations of their audience, find an implicit order in their subject matter and discover how they feel about the work. Pre- writing can be seen as any writing task that exposes students to self-assessment, observations and exploration of the world around the subject matter. The following are the writing tasks under pre-writing:

a. Observation, b. Imagining c.Clusteringd. Outlining e.Interviewing f. Brainstorming g. Watching movie etc.

The focus here is developing and ordering of facts. The task identified under pre-writing shows a kind of interactive process in the Cognitive principle. This is the same as the view of Massi (2001) that writing is by nature an interactive process that evolves out of the symbolic interplay between writer's mind, text and reader.

Writing: The major task here is putting a draft version on paper. This may feature free-writing or collaborative work. The writer uses the data got through the pre-writing stage as a springboard. The emphasis is on content and organization here.

Revising stage. This is also called Editing stage. This is the stage where the final work is presented. Revision can be done by peers or anyone. Errors are expected when writers write outside a given model. However, the recursive nature of the editing stage puts an end to the errors.

The Cognitive Approach to learning does not believe that knowledge is to be transferred by an expert to a novice rather it is building a new frontier of knowledge from existing ideas. Knowledge is generated or reconstructed by learners through an active, social process of meaningmaking: selecting information, originating hypotheses, investigating evidence, evaluating and relating new experiences to and building on existing mental constructs.

This pedagogical shift from behaviorism to constructivism has some great reaching effects on teaching and learning. An understanding of the nature of knowledge and how learners process it will inform teaching and practices. Bruner (1960)proposes that a theory of instruction should take into account:

- the learner's predisposition towards learning;

- how best to structure a body of knowledge to enable the learner to grasp it, manipulate the information and generate new propositions;

- how best to sequence material to be learnt to facilitate meaningful learning and

- the nature and pacing of feedback, rewards and punishments and how it influences learning.

Deriving from this are some key principles:

* Motivation is an important part of learning, and instruction must be adapted to the learner's cognitive abilities, experiences and contexts that make the student willing and able to learn.

* Students must be to build upon what he/she has already learned through the writing of many drafts.The exposure of learners to different pre-writing techniques facilitates the gathering of information for writing. The teacher as a facilitator should ensure learners engage in dialogue that prompts inquiry, cross-fertilization of ideas as well as structuring materials in such a way as to encourage extrapolation, and going beyond the information given but generating new ideas tending towards creativity. 


\section{WHY IS CREATIVITY SO IMPORTANT?}

According to the British National Curriculum (2001):-

(1) Creativity Improves Pupils' Self-esteem, Motivation and Achievement.Pupils who are encouraged to think creatively and independently become:

* More interested in discovering things for themselves. * More open to new ideas. * Keen to work with others to explore ideas. ${ }^{*}$ Willing to work beyond lesson time when pursuing an idea or vision.As a result, their pace of learning, levels of achievement and self-esteem increase.

(2) Creativity Prepares Pupils for Life: The students who are creative will be prepared for a rapidly changing world, where they may have to adapt to several careers in a life time. Many employers want people, who see connections, have bright ideas, are innovative, communicative and work well with others and are able to solve problems. In other words, they need creative people.

(3) Creativity Enriches Students' Lives. By promoting creativity, teachers can give all students the opportunity to discover and pursue their particular interests and talents. We are all, or can be, creative to some degrees. Creative students lead richer lives and in the long term, make a valuable contribution to society.

The onus then rests on the language teacher to examine how far this sub-skill can been enhanced in the language class especially in the continuous writing aspect with modern technology. It is to be noted that where students have been drilled effectively on how to write from independent frame of mind such exercise becomes future sustaining. Hubbard (2003) and (Akinwamide 2008)are of the view that, the mark of an effective teaching and learning is in the product (students) who afterward can display mastery by application of the long years of training. This is corroborated by the submission of Stanley (2007) that, it is a myth that all it takes to write is to sit down in front of a blank page, to begin at the beginning and write through to the end, with no planning, break, editing or changes in-between. We should not shy-away from the fact that all we want to write won't come to us at the same time hence the need to plan and check our writing all over again and again. The language teacher should try to make the writing class a creative environment.In addition, the language teachers can promote Creativity by the following ways.

1. At planning stage, the teacher can build creativity objectives into plan.

2. The teacher can give pupils clear achievable targets. Teacher can encourage students to comment, ask questions, promote and reward imagination and originality.

3. When reviewing work, the teacher can help pupils to develop criteria that they can use to judge their own work, in particular its originality and value. To this end, the language teacher should encourage the students to be imaginative, purposeful, and original and value oriented.

Creativity is addressed in the school certificate paper by checking the content relevance and the logical presentations of ideas. Students' essay work are considered appropriate when the subject matter required in the question is well addressed by the students. More often than not, some students veer off the topic and major on what may be regarded as the minor. It is not uncommon to come across essay work which is the product of others. Some students may copy other students or model essays written in the classroom or textbooks. The WAEC and NECO award mark for logical presentations of ideas also. This is under the caption 'Organization'. The above are put in place to check if the students consider, audience and purpose of writing.

\section{IMPLICATIONS}

Cognitivist teaching methods aim at assist students in assimilating new information to existing knowledge, and enabling them to make the appropriate modifications to their existing intellectual framework to accommodate that information. Thus, while cognitivists allow for the use of "skill and drill" exercises in the memorization of facts, formulae, and lists, they place greater importance on strategies that help students to actively assimilate and accommodate new material. For instance, asking students to explain new material in their own words can assist them in assimilating it by forcing them to re-express the new ideas in their existing vocabulary. Likewise, providing students with sets of questions to structure their reading makes it easier for them to relate it to previous material by highlighting certain parts and to accommodate the new material by providing a clear 
organizational structure. Now, because learning is largely self-motivated in this approach, cognitivists such as A. L. Brown and J. D. Ferrara have also suggested methods which require students to monitor their own learning. For instance, the use of ungraded tests and study questions enables students to monitor their own understanding of the material. Other methods that have been suggested include the use of learning journals by students to monitor progress and highlight any recurring difficulties, and to analyze study habits.

\section{REFERENCES}

[1] Adams, S(2006): A Process Approach to Writing. http://www. DevelopingTeacher.Com. A Web Site for the Developing Language Teacher.

[2] AkinwamideT.K. (2012) the Influence of Process Approach On English As Second Language Students' Performances in Essay Writing. ELT, Canadian Journal of Science and Education.

[3] Anthony B. (2005) Process Writing and Communicative-Task Based Instruction: Many Common Features but More Common Limitations? University of Seville

[4] Bander, R. (1971) American English Rhetoric: Writing from Spoken Models for Bilingual Students. New York Harper and Row.

[5] Bell J and B. Burnaby (1984) A Handbook for ESL Literacy. Toronto: 3, 55-68 Caudery, T. (1995) What the "Process Approach" Means to Practising Teachers of SecondLanguage Writing Skills. Teaching English as a Second or Foreign Language. Vol 1. No. 4

[6] Hubbard R. L. (2003) Communication Skills. Effective Education Publishing 11755 Riverview Drive. St. Louis/Missouri 63138 USA.

[7] Massi (2001),Interactive Writing in the EFL Class: A Repertoire of Tasks" THE INTERNET TESL JOURNAL Vol vii" No 6. June 2001 (Http://itesljiorg/Techniques/Massi writing Tasks. Html)

[8] Nunan, D. (2000), Designing Task for the Communicative Classroom. Cambridge, CambridgeUniversity Press.

[9] Pligrims(2007)Features of Creativity. Internet www.Teaching English Org. uk

[10] Stanley, G (2003) Approaches to Process Writing. British Council, Barcelona.

Citation:Akinwamide Timothy Kolade. "Highlighting the Cognitive Objectives on Writing Skill Development: The Creativity Paradigm"International Journal of Humanities Social Sciences and Education (IJHSSE), vol 6, no. 1, 2019, pp. 61-65. doi:http://dx.doi.org/10.20431/2349-0381.0601007.

Copyright: () 2019 Authors. This is an open-access article distributed under the terms of the Creative Commons Attribution License, which permits unrestricted use, distribution, and reproduction in any medium, provided the original author and source are credited. 